\title{
Change in chemical constituents and overall acceptability of frozen and dehydrated Aonla fruit pulp during storage
}

\author{
Jyoti Prabha Bishnoi ${ }^{*}$, Rakesh Gehlot ${ }^{2}$ and S. Siddiqui ${ }^{3}$ \\ ${ }^{1}$ Amity institute of Biotechnology, Amity University Rajasthan, Jaipur -303002 (Rajasthan), INDIA \\ ${ }^{2 \& 3}$ Centre of Food Science and Technology, CCS Haryana Agricultural University, Hisar-125004 (Haryana), INDIA \\ *Corresponding author. E- mail: uohjyoti@gmail.com
}

Received: December 15, 2016; Revised received: May 26, 2016; Accepted: August 19, 2016

\begin{abstract}
Ascorbic acid and total phenol in frozen aonla pulp on zero day of storage was found to be 365.5 $\mathrm{mg} / 100 \mathrm{~g}$ and $2.1 \mathrm{mg} / \mathrm{g}$ while in dehydrated aonla pulp it was $2.3 \mathrm{mg} / 100 \mathrm{mg}$ and $14.7 \mathrm{mg} / \mathrm{g}$ which was found to decrease with the increase in storage duration. However, significant increase (CD at $5 \%$ Level) in total soluble solids (TSS) and non-enzymatic browning was noticed with the advancement in storage duration. The decrease and increase in physico-chemical characteristics were more significant in dehydrated aonla pulp as compared to frozen aonla pulp. Mean score for sensory attributes of dehydrated aonla pulp at zero month of storage was fairly less than frozen aonla pulp. Moreover, there was more significant decrease in value of sensory attributes of dehydrated aonla pulp during six months storage period compared to frozen aonla pulp. Thus, present study was first in its kind to determine and compare chemical composition and overall acceptability of frozen and dehydrated aonla pulp obtained from aonla fruits cv. Chakaiya during storage for optimizing there use in further development of value added aonla product.
\end{abstract}

Keywords: Aonla, Chakaiya, Dehydrated, frozen, Physico-chemical, Pulp, Sensory characteristics

\section{INTRODUCTION}

Aonla (Emblica officinalis Gaertn), the Indian gooseberry, is one of the important indigenous medicinal fruit also known as "Amrit Phal". It is one of richest source of ascorbic acid (500-1,500 $\mathrm{mg} / 100 \mathrm{~g})$ used as a strong rejuvenator in Indian pharmacopoeia (Pathak and Ram, 2007) . Because of its significant medicinal and nutritive value, it finds a prominent place in ancient Indian mythological literatures like Vedas, Askandhpuran, Shivpuran, Ramayana, etc. It is extensively used in Ayurvedic and Unani systems of medicines for sound health as Chyavanprash, Trifla, Amrit Kalash and Churan (Pathak et al., 2003). Besides, it is used in cosmetics for enriching hair growth and pigments. Aonla fruit is highly acidic and astringent in taste (kumar and Nath, 1993); therefore, it is not popular as a table fruit, but has a great potential in processed forms. Having great potential for processing into quality products thus can create a great demand in national, as well as in international, markets. Several value added products have been developed from aonla such as pickles, candy, sauce, chutney, squash, jam, jelly, spread, barfi and ladoo etc. The aonla pulp and shreds are required as basic materials for most of the above-mentioned products. Freezing and dehydration of aonla as aonla pulp and shreds respectively is an important technique which can be applied efficiently to make the fruits available round the year and also to avoid market glut in the peak harvest. The freezing and drying of fruits and vegetables is one of the most common preservation processes used for improving the stability, because they minimizes physical and chemical changes during storage. Keeping these facts in mind, the present study was undertaken to develop and evaluate the change in chemical composition and overall acceptability of frozen and dehydrated aonla pulp during storage.

\section{MATERIALS AND METHODS}

Mature aonla fruits cv. Chakaiya was procured from local orchards, Hisar during 2013-2014. The fruits were washed thoroughly with clean running water to remove the dirt and other extraneous materials. After washing operation, aonla fruits were subjected to pretreatment (blanching in $2 \%$ brine solution $+2 \%$ alum solution $+0.2 \%$ KMS solution). The pretreated aonla fruits were cooled at room temperature for 30 minutes. Aonla segments were then separated from its stone and grated using fruit processor. Sodium benzoate $(1 \mathrm{~g} / \mathrm{kg})$ was mixed with the grated aonla pulp. It was packed in polypropylene (PP) jars and stored at $-18^{\circ} \mathrm{C}$ in deep freezer for six months. The grated aonla pulp was also dehydrated in a tray dryer at $50^{\circ} \mathrm{C}$ over night, packed in Low density polyethylene (LDPE) bags and stored at room temperature for six months. The stored aonla pulp was evaluated for physico-chemical (ascorbic acid, total phenols, TSS and browning) and sensory 
parameters (colour and appearance, taste, texture. mouthfeel and overall acceptability) at two months interval. Total soluble solids (TSS) were estimated at ambient temperature by hand refractometer $(0-32 \%)$ and the values were expressed as percent TSS. Ascorbic acid was analyzed according to AOAC (1990) method. Non- enzymatic browning (NEB) was determined according to the method of Ranganna (2008). Total phenols were analyzed as per the methods given by Amorium et al. (1997), while organoleptic evaluation by using 9 point hedonic scale.

\section{RESULTS AND DISCUSSION}

Changes in total soluble solids (TSS), ascorbic acid, total phenols and non-enzymatic browning in aonla pulp (frozen and dehydrated) during six months storage period in present study have been presented in Tables 1 and 2. Aonla pulp, both frozen and dehydrated, showed significant decrease (CD at 5\% Level) in ascorbic acid ( $17 \% \& 41 \%$ resp.) and total phenols ( $13 \% \& 33 \%$ resp.), and significant increase in total soluble solids (TSS) and non-enzymatic browning with the advancement in storage duration. Loss in ascorbic acid content could be attributed to oxidation of ascorbic acid to dehydro-ascorbic acid with passage of time. Similar findings have been confirmed by Damame et al. (2002) in aonla preserve stored at room temperature, Sharma et al. (2002) in aonla powder stored at room temperature for six months, Tandon et al. (2003) in aonla candy stored for nine months under ambient temperature, Choudhary et al. (2012) in aonla nectar stored at room temperature for 240 days and Vikram et al. (2012) in aonla herbal jam stored for eight months at ambient temperature.. The increase in

Table 1. Effect of storage period on chemical constituents of frozen aonla pulp.

\begin{tabular}{lccccc}
\hline Frozen aonla & \multicolumn{4}{c}{ Storage period (months) } & C.D. at \\
\cline { 2 - 5 } pulp & $\mathbf{0}$ & $\mathbf{2}$ & $\mathbf{4}$ & $\mathbf{6}$ & $\mathbf{5 \%}$ \\
\hline TSS (\%) & 11.1 & 11.2 & 11.38 & 11.5 & 0.23 \\
& 0 & 3 & & 9 & \\
Ascorbic Acid & 365. & 351. & 324.5 & 305. & 5.65 \\
(mg/100 g) & 5 & 3 & & 1 & \\
$\begin{array}{l}\text { Total phenols } \\
\text { (mg/g) }\end{array}$ & 2.10 & 2.00 & 1.87 & 1.64 & 0.07 \\
$\begin{array}{l}\text { NEB (OD at } \\
\text { 440 nm) }\end{array}$ & 0.02 & 0.02 & 0.038 & 0.05 & 0.05 \\
\hline
\end{tabular}

Table 3. Effect of storage period on sensory characteristics (9 point hedonic scale) of frozen.

\begin{tabular}{|c|c|c|c|c|c|}
\hline \multirow{2}{*}{$\begin{array}{l}\text { Frozen aonla } \\
\text { pulp }\end{array}$} & \multicolumn{4}{|c|}{ Storage period (months) } & \multirow{2}{*}{$\begin{array}{c}\text { C.D. at } \\
5 \%\end{array}$} \\
\hline & 0 & 2 & 4 & 6 & \\
\hline $\begin{array}{l}\text { Colour and } \\
\text { appearance }\end{array}$ & 8.1 & 8.0 & 7.8 & 7.5 & 0.35 \\
\hline Taste & 8.0 & 7.9 & 7.6 & 7.2 & 0.48 \\
\hline Texture & 8.0 & 7.8 & 7.6 & 7.1 & 0.42 \\
\hline Mouthfeel & 8.0 & 7.9 & 7.7 & 7.3 & 0.38 \\
\hline $\begin{array}{l}\text { Overall ac- } \\
\text { ceptability }\end{array}$ & 8.0 & 7.8 & 7.6 & 7.1 & 0.44 \\
\hline
\end{tabular}

TSS of dried as well as frozen aonla pulp in present study might be due to gradual loss of moisture and breakdown of complex molecules to simple form. Similar results were reported by Daisy et al. (2007) in aonla preserve stored at room temperature for three months and Ram et al. (2011) in aonla bael blended RTS beverage stored in refrigerated conditions. Decrease in tannins in present study might be due to activity of polyphenolase enzyme, which acts upon tannins and ascorbic acid, while increase in NEB might be due to condensation of tannins to brown pigments. Similar findings were obtained by Ahlawat (2007) in osmotically dehydrated aonla during 60 days storage period.

Effects of storage period on organoleptic quality (colour and appearance, taste, texture, mouthfeel and overall acceptability) of aonla pulp (frozen and dehydrated) cv. Chakaiya have been shown in Tables 3 and 4. Mean score for colour and appearance, taste, texture, mouthfeel and overall acceptability of frozen aonla pulp at zero month of storage were 8.1, 8.0, 8.0, 8.0 and 8.0, respectively. Mean score for colour and appearance, taste, texture, mouthfeel and overall acceptability of dehydrated aonla pulp at zero month of storage were 7.8, 7.5, 7.7, 7.2 and 7.5, respectively. Data clearly reveal that mean score for sensory attributes of dehydrated aonla pulp at zero month of storage was fairly less than frozen aonla pulp. A significant decrease in sensory attributes of aonla pulp (frozen and dehydrated) was noticed at the end of six months storage. Increase in non-enzymatic browning might be the reason for decrease in mean score for colour and appearance of aonla pulp. Textural losses might be due to loss of moisture, while significant decrease in mean score for taste and mouthfeel might be due to various

Table 2. Effect of storage period on chemical constituents of dehydrated aonla pulp.

\begin{tabular}{|c|c|c|c|c|c|}
\hline \multirow{2}{*}{$\begin{array}{l}\text { Dehydrated } \\
\text { aonla pulp }\end{array}$} & \multicolumn{4}{|c|}{ Storage period (months) } & \multirow{2}{*}{$\begin{array}{l}\text { C.D. at } \\
\mathbf{5 \%}\end{array}$} \\
\hline & $\mathbf{0}$ & 2 & 4 & 6 & \\
\hline TSS (\%) & 54.7 & 55.0 & 57.0 & 58.5 & 0.45 \\
\hline $\begin{array}{l}\text { Ascorbic acid } \\
(\mathrm{mg} / 100 \mathrm{mg})\end{array}$ & 2.3 & 2.0 & 1.7 & 1.1 & 0.2 \\
\hline $\begin{array}{l}\text { Total phenols } \\
(\mathrm{mg} / \mathrm{g})\end{array}$ & 14.7 & 12.5 & 11.1 & 9.8 & 1.1 \\
\hline $\begin{array}{l}\text { NEB (OD at } \\
440 \mathrm{~nm})\end{array}$ & 0.24 & 0.54 & 0.74 & 0.97 & 0.02 \\
\hline
\end{tabular}

Table 4. Effect of storage period on sensory characteristics (9 point hedonic scale) of dehydrated aonla pulp.

\begin{tabular}{|c|c|c|c|c|c|}
\hline \multirow{2}{*}{$\begin{array}{l}\text { Dehydrated } \\
\text { aonla pulp }\end{array}$} & \multicolumn{4}{|c|}{ Storage period (months) } & \multirow{2}{*}{$\begin{array}{c}\text { C.D. at } \\
\mathbf{5 \%}\end{array}$} \\
\hline & $\mathbf{0}$ & 2 & 4 & 6 & \\
\hline $\begin{array}{l}\text { Colour and } \\
\text { appearance }\end{array}$ & 7.8 & 7.2 & 6.7 & 5.8 & 0.32 \\
\hline Taste & 7.5 & 7.1 & 6.4 & 5.7 & 0.35 \\
\hline Texture & 7.7 & 7.2 & 6.7 & 5.7 & 0.27 \\
\hline Mouthfeel & 7.2 & 6.9 & 6.3 & 5.5 & 0.42 \\
\hline $\begin{array}{l}\text { Overall ac- } \\
\text { ceptability }\end{array}$ & 7.5 & 7.0 & 6.5 & 5.7 & 0.33 \\
\hline
\end{tabular}


chemical reactions. Similar results were reported by Verma and Gupta (2004) in solar dried aonla flakes stored at room temperature and Singh et al. (2014) in bael fruit pulp stored under refrigerated conditions. Decrease in value of sensory attributes was found to be more significant in dehydrated aonla pulp as compared to frozen aonla pulp. Data clearly reveal that mean scores for sensory attributes of dehydrated aonla pulp were well below the acceptable limit i.e. mean score for various sensory attributes is below six (liked slightly) at the end of six months storage. Similar results were reported by Askar and Treptow (1993). Thus, dehydrated aonla pulp was found acceptable only up to three months of storage, while frozen aonla pulp was found acceptable even beyond six months of storage. Sagar and Kumar (2006) reported similar results in ready to eat dehydrated aonla shreds stored at room temperature as well as frozen storage.

\section{Conclusion}

It can be concluded from the present investigation that TSS and non-enzymatic browning (NEB) increased significantly in frozen as well as dehydrated aonla pulp during six months storage. The increase in TSS and NEB were relatively more in dehydrated aonla pulp as compared to frozen aonla pulp. Ascorbic acid and total phenols decreased significantly in frozen as well as dehydrated aonla pulp during six months storage. The decrease in ascorbic acid and total phenols were relatively more in dehydrated aonla pulp as compared to frozen aonla pulp. During storage, the overall acceptability scores of frozen aonla pulp were found to significantly more as compared to dehydrated aonla pulp. Frozen aonla pulp was found quite acceptable after six months storage with minimum change in its organoleptic quality, while dehydrated aonla pulp became unacceptable after six months storage. Therefore, dehydrated aonla pulp was not found suitable for developing aonla product after six months storage. Thus, present study was first in its kind to determine and compare chemical composition and overall acceptability of frozen and dehydrated aonla pulp obtained from aonla fruits cv. Chakaiya during storage for optimizing there use in further development of value added aonla product

\section{ACKNOWLEDGEMENTS}

The present work was investigated under the guidance of elite members of advisory committee; Dr. Rakesh Gehlot, Dr. Saleem Siddiqui, Dr. S.K. Sehrawat and Dr. Manju Tonk, Faculty Members at CCS, Haryana Agricultural University (HAU), Hisar, Haryana-125 004 for their inexhaustible encouragement and sincere co-operation and HAU for providing funds.

\section{REFERENCES}

A.O.A.C. (1990) Official Methods of Analysis. Association of Official Analytical Chemists. Washington, D.C. $15^{\text {th }}$ edi- tion.

Ahlawat ,M. (2007) Development of osmo-dehydrated aonla (Emblica officinalis Gaertn.). M.Sc. Thesis, CCS Haryana Agricultural University, Hisar, India.

Amorium, H.V., Dougall, D.K. \& Sharp, W.R. (1997) The effect of carbohydrate and nitrogen concentrations of phenol synthesis in plant scarlet rose cells grown in tissue culture. Physiologia Plantarum, 39, 91-95.

Askar, A. and Treptow, H. (1993) Quality assurance in tropical fruit processing. Springer Verlag, Berlin, pp. 89-125.

Choudhary, M. L., Verma, I.M., Singh, J. and Godara, S.L. (2012) Studies on aonla (Emblica officinalis G.) nectar and biochemical changes with advancement of storage period. Asian Journal of Horticulture, 7(1), 128-132.

Daisy, Gehlot, R. and Singh, R. (2007) Studies on physicochemical composition and changes in bio-chemical constituents of aonla fruits cv. Banarasi during processing into preserve. Haryana Journal of Horticultural Science, 36(3and4), 247-248.

Damame, S.V., Gaikwad, R.S., Patil, S.R. and Masalkar, S.D. (2002) Vitamin C content of various aonla products during storage. Orissa Journal of Horticulture, 30 (1), 19-22.

Kumar, S. and Nath, V. (1993) Storage stability of aonla fruits: a comparative study of zero energy cool chamber versus room temperature. Journal of Food Science and Technology, 30(3), 202-203.

Pathak, R.K. and Ram R.A. (2007) Organic production of aonla In: National seminar on " Recent advances in production, protection and post harvest management of grape, mandarin and arid fruits". Collage of Horticulture, Mandsaur, pp 133-136

Pathak, R.K.; Pandey, D.; Mishra, A.K.; Haseeb, M. and Tandon, D.K. (2003) The Aonla, CISH, Lucknow, pp.32.

Ram, R.B., Meena, M.L., Sonkar, P., Lata, R. and Upadhyay, A.K. (2011) Standardization and evaluation of blended aonla (Emblica officinalis G.) and bael (Aegle marmelos) RTS beverages. Plant Archives, 11(1), 205-208.

Ranganna, S. (2008) Handbook of Analysis and Quality Control for Fruit and Vegetable Products. Tata McGraw Hills Publishing Co. Ltd., New Delhi.

Sagar, V.R. and Kumar, R. (2006) Preparation and storage study of ready-to-eat dehydrated gooseberry (aonla) shreds. Journal of Food Science and Technology, 43(4), 349-352.

Sharma, S.R., Alam, S. and Gupta, S. (2002) Storage studies on dehydrated aonla powder. In: souvenir, Convention of Indian Society of Agricultural Engineers, 35, 155-156.

Singh, A., Sharma, H.R., Kumar, N. and Upadhyay, A. (2014) Effect of pretreatments on physical and thermal properties of Beal (Aegle Marmelos Correa) fruit pulp during storage. Austin Journal of Nutrition \& Food Sciences, 2(4), 8.

Tandon, D.K., Yadav R.C., Sood S., Kumar S. and Dikshit A. (2003) Effect of blanching and lye peeling on the quality of aonla candy. Indian Food Packer, 57, 147-152.

Verma, R.C. and Gupta, A.K. (2004). Effect of pretreatments on quality of solar dried amla. Journal of Food Engineering, 65(3), 397-402.

Vikram B., Man, B., Narayan, S. and Prasad, V.M. (2012) Effect of dried powder of Tulsi leaf, Ginger and Cardamom addition on Aonla Jam with granulated particles of Cashew. Environment and Ecology, 30 (3A), 635-640. 